\title{
Impact of training and development function on enhancing competitiveness capacity (An Empirical study of Jordanian industrial companies from managers perspective)
}

\author{
Salih A. Jaradat \\ Jadara University, Irbid, Jordan, Faculty of Economic and Business, Business \\ Administration Department. E-mail: francanabelyoon@hotmail.com
}

Received: June 15, 2014

Accepted: August 5, 2014

Published: June 12, 2015

doi:10.5296/bms.v6i1.7803

URL: http://dx.doi.org/10.5296/bms.v6i1.7803

\begin{abstract}
The purpose of this study is to examine the impact of training and development function on enhancing competitiveness capacity for Jordanian industrial companies. The variables of this study consisted of independent variable ( Training and development function) and dependent variable ( enhancing competitiveness capacity) .

The study employed the statistical analytical descriptive approach based on the literature review approach and field work to test the study hypotheses. The population of this study consisted of Jordanian industrial companies. A sample consisted of (30) general managers and department managers as a respondents of this study, the researcher targeted industrial companies which was selecting randomly . The study used questionnaire as a tool to collect data to measure study sample individuals attitudes toward the impact of training and development function on enhancing competitiveness capacity for Jordanian industrial companies.

The findings of the study indicates that there is high correlation relationship between independent variable and it's dimensions with dependent variable, and there is positive impact of training and development function on enhancing competitiveness capacity for Jordanian industrial companies.
\end{abstract}

The study recommends to apply this study on the other sectors by researchers in the future, 
establish professional training unit in every medium and large industrial company, and deduct a reasonable ratio from it's annual profits for training.

Keywords: Training, development, strategic, Integrating, requirement, evaluation, enhancing, competitiveness 


\section{Introduction}

Training is an awareness and planned efforts aim to assist, encourage and motivate employees to acquire knowledge, skills, capabilities, attitudes and new behavior to apply during the work in the present and in the future. ( Noe et al.,2011) In order to aid organization to achieve its goals, and work by full efficiency and effectiveness, in addition to achieve competitive advantage. (Jackson et al., 2004, 2009). The researcher adopts wide insight for training to include development, formalization, socialization, and orientation because it connects to each other and it is very difficult to separate or recognize.

The human resources development is to increase knowledge acquisition, skills, competences, and positive attitudes and behaviors via continuing and to reach professionalism, excellence, innovation and entrepreneurship via planned development. Training and development strategy has vital importance for organization wither it is in the present and future,

It is considered as cornerstone to HR and prosperity key to achieve organization goals. The designing and carrying out the training programs and activities by high efficiency and effectiveness may contribute in achieving critical advantage by different ways.

To achieve successful training and development for organization ,the programs should revise and renew from time to another to give employees more flexibility, and should connect with rewards and incentives. In addition to allocate special financial budget to support training process.

Training and development is a vital tool for organizational competitiveness, management training, leadership, skills language and technical skill training, should be the interest of the management of industrial companies.

Training both physically, intellectually and mentally are very essential in facilitating not only the level of productivity but also the development of personnel in any organization. There for, training can be put in a contact relevant to school administrators. However, knowledge is the ability, the skill, the understanding, the information, which every individual requires.

Acquiring in order to be able to function effectively and perform efficiently. Human resources, are the most valuable assets of any organization, with the machines, materials and even the money, nothing done without man-power.

Usually, before training or development programs are organized efforts are being made through individuals and organizational appraisals to identify the training needs.

Training has been observed as part of human development ,human development is a process of enlarging peoples choices.

In principle, these choices can be infinite and change over time. But at all levels of development, the three essential ones are for people to live a long and healthy life, to acquire knowledge through training, and to have access to resources needed for a decent standard of living.If these essential choices are not available many other opportunities remain 
inaccessible.

\section{Literature Review}

Training and development has been given various definition by various authors. In fact there seems to be no definition that can stand on its own as every definition seems to complement one another.(Olusanya,Samuel et al., 2012). Training is organization efforts aimed at helping an employee to acquire basic skills required for the efficient execution of the functions for which he has hired, while development deals with the activities undertaken to expose an employee to perform additional duties and assume positions of importance in the organizational hierarchy.

Vbekn, (1975) defined management training as the process of developing managers knowledge, skills and attitudes through instruction, demonstration, practice and planned experience to meet the present and future needs of the organization.

The training and development refers to the process to option or transfer knowledge, skill and abilities needed to carry out a specific activity or task; therefore, benefits of training and development both for employer and employees are strategic in nature and hence much broader. In order, to meet the current and future challenges of business, training and development assumes a wide range of learning actions, ranging from training of the employees for their present tasks and more so, knowledge sharing to improve the business horizon and customers service. It also focuses on their career development, thus expanding individual, group and organizational competitiveness. A comprehensive training and development program helps in deliberating on the knowledge, skills and attitudes, necessary to achieve organizational goals and also to create competitive advantage (peteraf, 1993).

In order to ensure that employees are equipped with the right kind of skills knowledge and abilities to perform their assigned tasks, training and development plays its crucial role towards the growth and success of business. By choosing the right type of training we ensure that employees possess the right skills for business, and the same need to be new HR practices.

The need for developing employees is compelling because a sound training and development plan has its contributions to increase productivity and quality of work. The development strategy reduces staff turnover and absenteeism and also helps in improving motivation among the employees. In order to stay ahead of competition. Training and development plan must in corporate innovation and reinvention and this is only possible when training encompasses a wide range of learning actions. Therefore, an ideal training shall become part of a company-wide strategy and it must be linked to business goals and organizational performance.

The value of a successfully managed developmental process is the same both for the individual and the company. Combination of work and education, as well as their harmonization is an essential requirement of a modern and future worker and organization. 
The demand for well-developed and expert human resources is changing more quickly than the human resources themselves. Therefore, it is necessary to build a new strategy for human resource development. Only high-quality workers of knowledge may carry and sustain competitive advantage, and only such human resources can follow the modern day business operations characterized by quick, dynamical, complex and unpredictable changes. (Jelena,Vemic Durkovic, 2009).

Successful global organization are focused on education and development of their employees in order to make use of their knowledge and skills for important of organizational strategies is possible only if the employees posses knowledge and skills necessary to implement those strategies. Thus, education and development are becoming a strategic imperative for modern companies.(Jelena, Vemic Durkovic, 2009).

Specifically, by investing into employee education and development the company increase the value in value chain, productivity, product or service quality, customer or buyer satisfaction and so on. This finally leads to increased success and competitiveness of the company.

The process of employee development un folds in the manner that stimulates creativity and inventiveness and shapes the entire organizational knowledge, which unifies the organization and makes it different from any other, in order to maintain its position and increase competitive advantage, the organization needs to be able to create new knowledge instead of relying on the existing, once responsibility and privilege of those of higher position and expert jobs, today development and education are responsibility and requirement for all.

The bigger the organizations are, the more assets the spend on education and provide their employees with greater and more diverse development possibilities.

Training is a tool that can assist organizations in building a more committed and productive work force. By helping to establish employee investment reciprocity identification, and by limiting alternative employment options, and effective training program can lead to greater commitment and less employee turnover. The result is on organization that is more productive and professional. Although training can play a major role in this process, organizations need to look at additional work force strategies and practices that can enhance commitment. Training alone may offer that can enhance commitment. Training alone may offer many benefits but a much greater impact will be found when using a strategy to human resources that entails many different organizational commitment practices and policies, organization need to fully achieve commitment (Heyes et al., 1996). An effective training program is one such organizational practice that can lead to greater employee commitment and a more stable work force.

The four - step training process includes needs analysis instructional design, implementation, and evaluation.

Trainees need to be motivated to learn ensuring that they are motivated involves making the 
learning meaningful, making skills transfers easy, and reinforcing the learning.

Whatever the training program, it's important to evaluate the training effort, you can measure reaction, learning, behavior, or results, Ideally using a control group that is not exposed to training, in parallel with the group that your are training. (Desslar, Gary, 2011: 323).

\subsection{Strategic Importance of Training and Development}

Training and development contributes with enhancing competitiveness capacity for company through giving a chance of employees.

Gradually career to employees and providing them with new knowledge, competences and skills. Training also contributes with enhancing affiliation to the company, improving performance, understanding modern technology and techniques and increasing productivity. although, training and development contributes with understanding customers needs through acquisition communication and selling skills, promoting reputation level of the company.

Acquisition, Training and development contributes with understanding learning importance and sustain company and its prosperity.

Training and development contributes with benefiting from merger and acquisition cases, forming talents inventory and transferring company from traditional to learning company

\subsection{Integrating of Training and Development Function with Other HRM Functions.}

Integrating of training and development function contributes with enhancing competitiveness capacity for company through knowing training needs, job analysis and job design level, selection and placement requirements, combining employees performance evaluation and compensation with training level, planning for company needs of $\mathrm{HR}$, and combining between employees behavior with outcomes.

\subsection{Successful Training Requirements}

Training requirements contributes with enhancing successful competitiveness capacity for company through top management support, employees readiness, desire, motivation, social support, suitable work environment, availability of special training unit, financial budget, training means, sharing information, selection and placement, experienced employees to become trainers, issuing booklets, rewarding trainees and trainers.

\subsection{Training and Development Evaluation}

Training and development evaluation contributes with enhancing competitiveness capacity through providing indicators which produce thoughts about improving and performance training, attracting more qualified applicants, measuring return on investment, sharing value added to the employees.

Generally speaking, the training and development generates excellence, professionalism and innovation for the employees who participate with different training programs, which may 
achieve competitive advantage for the company.

\section{Competitiveness}

One of the most prominent and widely respected researchers in the area of competitiveness is Michael Porter. According to( Porter, 1998), a firms competitiveness refers to the competitive advantage over its rivals in a particular industry. A firm has competitive advantage when it is able to differentiate itself in market place, generate greater revenues and operates at lower costs than its competitors, in addition, innovation the application of new ideas to the products, processes or any other aspects of firms activities( Rogers, 1998: 5) has become one of the key drivers for firms to operate profitably and compete sustainably in the globally linked economies.

Porter \& Stern, (2002) asserted that firms operating in advanced nations whose economies were innovation based would not option sustained competitive advantage, if they were not able to create and then commercialize new products and processes and shift the technology frontier as fast as their rivals can catch up. This implies that innovation is a key to obtaining a sustained competitive advantage.

Theoretical establishment in business strategy has elevated the role of human resources, both as a business function and as a labor, in creating sustained competitive advantage. The resource - based view of the firm.( Barney, 1986, 1991, 1995) proposed that firms could create and obtain sustained competitive advantage by creating value in a fashion that is rare and impossible for rivals to imitate.

The resource - based view of the firm argues that conventional sources such as natural resources, technology, economies of scale, operational and manufacturing designs etc; can be utilized to generate sustained competitive advantage, yet these sources can be easily copied by competitors. In this case, any sources of sustained competitive advantage that cannot be easily imitated are especially important. The resource - based view of the firm established that people (human resources), a repository of knowledge and skills, can be leveraged to create value in a way that is difficult for competitor to imitate (Barney, 1991)

Porter, (1980) proposed three general types of strategies that are commonly used by business: they are cost leadership strategy, differentiation strategy, and focus strategy. Cost leadership strategy refers to the extent that the firm operates at low cost in an industry, for a given degree level of quality compared to its rivals. If the price war takes place in the industry, the firm can remain profitable, yet their competitors suffer losses. When the firm develops a product or service with unique attributes which are perceived or valued by customers to be better or different from the same products offered by the rivalry in the industry, the firm is said to employed differentiation strategy. The firm employs the focus strategy to concentrate on a narrow market segment, and with that particular segment the firm attempts to obtain either a cost advantage or differentiation.

Hendry, (1991) examined the function of training as part of the broader human resource 
strategies of a range of firms in UK and developed a frame work that allowed training to become a response in the competitive environment. Moreover, training has been frequently perceived to be integrated with broader structural change and innovation inside the firms.( Billet \& Cooper, 1997) business strategy focuses on improving the competitive position of a company, or business units products or services within the specific industry or market segment that the company important because research shows that business unit effects have double impact on overall company performance than do either corporate or industry effects. Business strategy can be competitive (batting against all competitors for advantage) and or cooperative (working with one or more companies to gain advantage against the competitors). Just as corporate strategy asks what industries the company should be in , business strategy asks now the company or its units should compete or cooperate in each industry. (Wheelen Hunger, 2010:231).

Porter further proposes that a firms competitive advantage in an industry is determined by its competitive scope, that is, the breadth of the company's or business units target market. Before using one of the two generic competitive strategies (lower cost or differentiation), the firm or unit must choose the range of product varieties it will produce, the distribution channels.

It will employ, the types of buyers it will serve, the geographic areas in which it will sell, and the array of related industries, which it will also compete. This should reflect an understanding of the firm's unique resources. Simply put, a company or business unit can choose a broad target or a narrow target. Combining these two types of target markets with two competitive strategies results in the four variations of generic strategies.

Lower cost strategy is the ability of a company or a business unit to design, produce, and market a comparable product more efficiency than it is competitors.

Differentiation strategy is the ability of a company to provide unique and superior value to the buyer in terms of product quality, special features, or after - sale service.

Cost focus strategy is a low - cost competitive strategy that focuses, on a particular buyer group or geographic market and attempts to serve only this niche, to the exclusion of others.

In using cost focus, the company or business unit seeks a cost advantage in its target segment.

Differentiation focus, like cost focus, concentrates on a particular buyer group, product line segment or geographic market.( Wheelen \& Hunger, 2010: 233 - 236).

Competition is a competitiveness process among industrial companies to gain bigger market share, customers satisfaction and their loyalty to its products, trade mark and achieve desire results and goals.( Coulter, 2005: $191-195$ ).

Competitive rivals are organizations with similar products and services aimed at same customer group (that is, not substitutes). There are number of additional factors directly affecting the degree of competitive. Rivalry in an industry or sector as competitor balance, 
industry growth rate, high fixed costs, high exit barriers and low differentiation. (Johnson \& Scholes, 2008: 64). Competitiveness might be improved by collaboration to increase selling power, buying power, barriers to entry, stake holder expectation, sharing work with customers, entry to new markets and decreasing risk of substitution.(Johnson \& Scholes, 2008: 241).

The successful competitiveness may competitive advantage for organization. Whereas competitive advantage is a concept which describes the degree of relative advantage possessed by an enterprise within its sector or markets as compared with other organization with which it directly or indirectly competes, or within its use of people, finance, and resources must be compared,( Johnson. G. Scholes. K, 2008).

M.E porter (1985) comment that competitive advantage is at the heart of firms performance in competitive advantage are everywhere where in firm (most) every department, facility, branch office, and other organizational unit has a role that must be defined and understood. All employees regardless of their distance from the strategy formulation process most recognize their role in helping a firm to achieve and sustain competitive advantage.

Competitive advantage may classify for two categories value and source which build on.

Competitive advantage is an important element which gives an essential chance for the organization to achieve many indicators which used to indicate that the organization possess a competitive advantage as willing strength, low cost, market share, trading reputation, customers satisfaction, uniqueness, imitating difficulty, work flexibility. Technology, employment, productivity, profitability and quickness delivering goods to customers.

Competitive advantage is the unique status which the organization has develop through the effective usage for essentials connected with competitive advantage which may had to high performance, if the organization can control of effective factors during the carrying out of the strategy.

Sustainable competitive advantage mainly depend on available number of conditions as continuing gaining by customer on more big value when he selects organization products comparing with competitors who are working in the same industry. The difference is more big value in the direct result of gap among organization capabilities and competitors.

According to these paragraphs we will see how the training and development as one of the HRM practices contribute in enhancing the degree of competitiveness of industrial companies.

On the other words, to enhance the competitiveness capacity for company ,company should be able to do one or more of the following activities as , downsizing the production cost , producing goods with high quality, that is difficult to imitate by its competitors, increasing production and improving productivity, improving employees and whole company performance, rehabilitating company staff, that is difficult to imitate by its competitors , increasing value added to every functional steps, promoting the skills degree for employees, improving management methods, commitment with supplying goods in the right time and 
place to the customers, accessing distribution channels, decreasing products delivery time, decreasing manufacturing cycle, designing excellence trade mark, designing excellence trade mark, using economic scale method, using modern technology and techniques, acquisition knowledge and skills, investing knowledge capital .

Although attempting to gain market share, maintaining protecting company's resources from sabotage and wasting, developing and diverse company's products, and using electronic commercial method to carry out its works by short time .

Industrial companies should satisfy with innovation , excellence, professionalism and follow the total quality management rules .

\section{Previous Studies}

Olusanya, Samuel Olumuyiwa, et al. (2012) Training and development, a vital tool for organizational effectiveness. (A case study of sterling bank Nigeria plc)

The result of study reveals that staff training and development has a significant effect on organizational effectiveness and that staff training and development has enhanced employees performance in sterling bank Nigeria plc. There for, the study recommend and conclude that the training and development is a vital to achieve organizational effectiveness in starling bank Nigeria plc and management training, leadership. Skills, language and technical skills training, should be the interest of the management of sterling bank Nigeria plc.

Vichet Sum, (2010) integrating in business strategies means greater impact of training on the firms competitiveness. This paper, using the resource - based view of the firm as theoretical back ground, is to determine whether the integration of training in the firm business strategies increases the impact of training on the firms competitiveness. A regression analysis of the data obtained from a survey of training professionals employed in small, medium, and large firms across three different industries reveals a statistically significant positive regression coefficient, $\mathrm{b}=0.554$.

$$
\mathrm{T}(97)=6.25, \mathrm{p}<0.001
$$

Jelena, vemic Durkovic, (2009) development of human resources as strategic factors of the companies competitive advantage. The main starting point of this article is the idea that knowledge, as the result of the employees development, is becoming at strategic resource and center of competitive advantage and differentiation in modern economy. Attempting to change from within to adjust to external changes. Modern organization encourage development of enabling them to change the employees knowledge and skill structure as the basis of organizational development.

Scott Brum, (2007) what impact does training have one employee commitment and employee turnover?

Training is of growing importance to companies seeking to gain an advantage among competitors, there is significant debate among professionals an scholars as to the affect that 


\section{Macrothink}

training has no both employee and organizational goals. One school of thought argues that training leads to an increase in turn over while the other states that training is a tool to that can lead to higher levels of employee retention.

Becker, ( 1993 ). Regardless of where one falls within this debate, most professionals agree that employee training is a complex human resources practice that can significantly impact a company's success.

The training industry as a whole has show significant growth through the years. Statistics indicate that investment in training is continuing to grow as more as more companies realize its importance. As the investment in various training programs continue to rise, it becomes even more imperative for employers to understand the impact that training has on their organization.

\section{Methodology}

\subsection{Study Population and Sample}

The population of this study consisted of Jordanian industrial companies. A sample consisted of (30) industrial l companies, selected by randomly process.

The sample size was (30) general managers and department managers of (30) industrial companies.

\subsection{Study Model and Hypotheses}

\subsubsection{Study Model}

Impact of training and development function on enhancing competitiveness capacity for Jordanian industrial companies

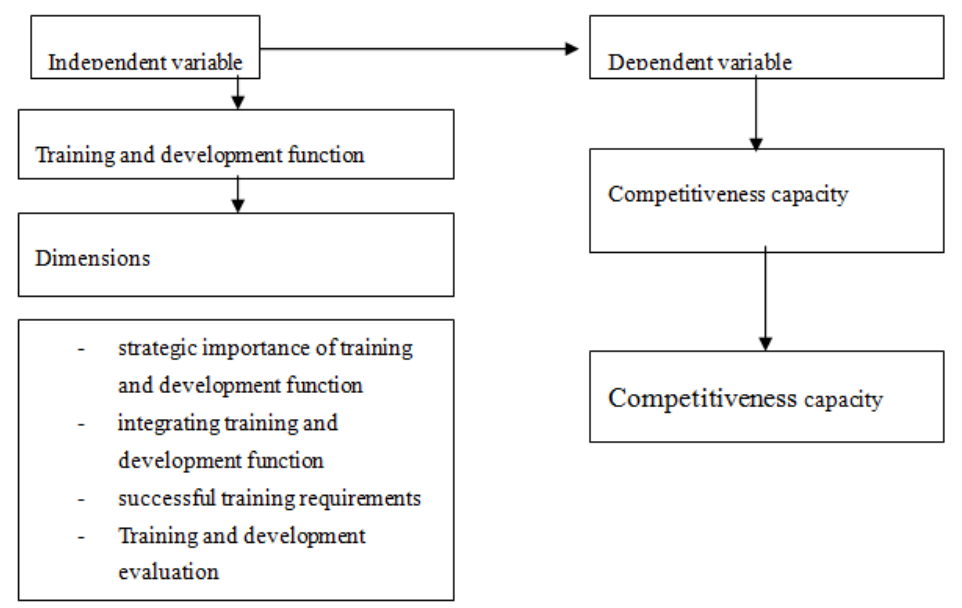

\subsubsection{Hypotheses}

Main hypothesis

There is no impact with statistical significant at significant level $(0,05 \geq \alpha)$ of training and 
development function on enhancing competitiveness capacity for Jordanian industrial companies.

sub hypothesis No. 1

There is no impact with statistical significant at significant level $(0.05 \geq \alpha)$ of strategic importance of training and development function on enhancing competitiveness capacity for Jordanian industrial companies.

Sub hypothesis No. 2

There is no impact with statistical significant at significant level $(0.05 \geq \alpha)$ of integrating training and development function with other HRM functions on enhancing competitiveness capacity for Jordanian industrial companies.

Sub hypothesis No. 3

There is no impact with statistical significant at significant level $(0.05 \geq \alpha)$ of successful training requirements on enhancing competitiveness capacity for Jordanian industrial companies.

Sub hypothesis No. 4

There is no impact with statistical significant at significant level $(0.05 \geq \alpha)$ of training and development evaluation on enhancing competitiveness capacity for Jordanian industrial companies.

\subsection{Data Analysis}

Descriptive statistics was used to analyze the primary data which is collected by using questionnaire which was divided into three parts, the first part included the study sample individuals characteristics, the second part included the dimensions of independent variable (37) items, the third part included the dependent variable (30) items, the data was analyzed by using SPSS to get, means, standard deviations, $\mathrm{t}$ - test, $\mathrm{f}$ - test, correlation coefficient, and multiple regression.

\subsection{Research Instrument (Validity and Reliability)}

Study collected the data by using an administered questionnaire based on literature review, the researcher made pre - test to the questionnaire by academic professionals in business administration field and by respondents general managers and departments managers to ensure of the validity and reliability of the questionnaire, and to ensure that the respondents understand the items and the overall format were easily understood.

Further researcher tested the questionnaire with representatives of Jordanian industrial companies to increase the clarity of the questions and avoid interpretation errors.

The researcher examined the instrument of this study by using data tool many times to measure the understanding degree of respondents in the same time and in sequence times. 
Coefficient of Chronbach alpha was extracting by SPSS, the results of items was $(0.71-$ 0.84 ) and for the whole questionnaire was (0.85).

Where the studies indicated to accept reliability coefficients, and its values are accepting for application purpose, although most studies indicated that the acceptance ratio for reliability coefficient is (0.60)(Amir and Sonder Pandian, 2002).

\section{Data analysis}

To verify the study tool reliability and its application, a 10 questionnaires were distributed to (10) general managers of companies twice with different time (two weeks ) to find Pearson correlation coefficient among attitudes toward study dimensions and the questionnaire as a whole two times. Chronbach Alpha was applied on all study dimensions items and questionnaire as a whole. Table No. 1 illustrates the reliability factors and Pearson correlation coefficient .

Table 1. Chronbach Alpha and Pearson correlation coefficient for study dimensions and questionnaire as a whole $(\mathrm{n}=10)$

\begin{tabular}{|c|l|l|l|}
\hline Number & Dimension & $\begin{array}{c}\text { Reliability } \\
\text { coefficient }\end{array}$ & $\begin{array}{c}\text { Correlation } \\
\text { coefficient }\end{array}$ \\
\hline 1 & Strategic importance of training and development & 0.72 & $0.74^{*}$ \\
\hline 2 & $\begin{array}{l}\text { Integrating of training and development function with } \\
\text { other HRM functions }\end{array}$ & 0.71 & $0.72^{*}$ \\
\hline 3 & Successful training requirements & 0.80 & $0.73^{*}$ \\
\hline 4 & Training and development evaluation & 0.76 & $0.74^{*}$ \\
\hline 5 & Enhancing competitiveness capacity & 0.84 & $0.72^{*}$ \\
\hline 6 & Questionnaire as a whole & 0.85 & $0.77^{*}$ \\
\hline
\end{tabular}

With statistical significant at significant, level $(0.05 \geq \alpha)$

Table No. 1 indicates that as follows.

- All reliability coefficient values by Chronbach Alpha was acceptable for application purpose. Where it was between $(0.71-0.85)$, where the studies indicated to accept reliability coefficients and all values are acceptable for application purposes, most studies indicated the reliability coefficient acceptable ratio (0.60), (Amir and Sonder Pandian, 2002).

- All Pearson correlation coefficient values are statistical significant at significant level $(0.05 \geq \alpha)$. Therefore it is indicating to application reliability.

\subsection{Study Sample}

Study sample consisted of (30) industrial company general managers which selected by 
randomization process from study population, table No. 2 illustrates study sample individuals distribution according to variables characteristics.

Table 2. Study sample individuals distribution according to Characteristics variable $n=30$

\begin{tabular}{|c|c|c|c|}
\hline Variable & Level & Repetition & Percent \\
\hline \multirow{5}{*}{ Age } & Less than 30 & 3 & 10.0 \\
\hline & 30 - less than 40 & 6 & 20.0 \\
\hline & 40 - less than 50 & 16 & 53.3 \\
\hline & More than 50 & 5 & 16.7 \\
\hline & Total & 30 & 100.0 \\
\hline \multirow{4}{*}{ Scientific qualification } & Diploma & 6 & 20.0 \\
\hline & Bachelor degree & 22 & 73.3 \\
\hline & Master and $\mathrm{PhD}$ & 2 & 6.7 \\
\hline & Total & 30 & 100.0 \\
\hline \multirow{3}{*}{ Current job } & General manager & 18 & 60.0 \\
\hline & Management manager & 12 & 40 \\
\hline & Total & 30 & 100.0 \\
\hline \multirow{5}{*}{ Years of experience } & 3 - less than 6 & 6 & 20.0 \\
\hline & 6 - less than 9 & 20 & 66.7 \\
\hline & $\begin{array}{l}9 \text { - less than } 12 \\
12 \text { - less than } 15\end{array}$ & 2 & 6.7 \\
\hline & More than 50 & 2 & 6.7 \\
\hline & Total & 30 & 100.0 \\
\hline
\end{tabular}

Table 2 illustrates that:

1. The higher percent for sample individuals distribution reached according to the age variable (53.3\%) (40-49) while the lower percent reached (10.0\%) for less than (30) years.

2. The higher percent of sample individuals distribution reached (73.3) according to scientific qualification variable bachelor degree, while the lower percent reached $(6.7 \%)$ for high studies.

3. The higher percent of sample individuals distribution reached (60.5\%)according to current job of general manager. While the lower percent reached (3.3\%) according to others.

4. The higher percent of sample individuals distribution reached(66.7\%) according to the number of experience years 9- than12, the lower percent reached (6.7\%) for 12-less than 15 years and more than 15 years.

\subsection{Statistical Analysis Results and Hypotheses Test}

Firstly: the results which related to the means 


\section{Ml Macrothink}

Table 3. Means and standard deviations for study sample individuals attitudes toward dimensions of independent variable which descending order

\begin{tabular}{|c|l|l|l|l|c|}
\hline rank & Number & dimensions & Mean & $\begin{array}{c}\text { Standard } \\
\text { deviation }\end{array}$ & $\begin{array}{c}\text { rating } \\
\text { degree }\end{array}$ \\
\hline 1 & 1 & $\begin{array}{l}\text { The strategic importance of training and } \\
\text { development }\end{array}$ & 4.21 & 0.75 & High \\
\hline 2 & 2 & $\begin{array}{l}\text { The integrating of training and } \\
\text { development with other HRM Functions }\end{array}$ & 4.13 & 0.77 & High \\
\hline 3 & 3 & Successful training requirements & 4.12 & 0.72 & High \\
\hline 4 & 4 & Training and development evaluation & 3.93 & 0.81 & High \\
\hline & & Independent variable & 4.12 & 0.68 & High \\
\hline
\end{tabular}

Table 3 illustrates that the means of study sample individuals attitudes toward all dimensions of independent variable was (3.93-4.21) with high rating degree to all dimensions, where the strategic importance of training and development dimensions came as the first rank with mean (4.21), and the integrating of training and development function with of other HRM functions came as a second rank with mean(4.13) while the successful training requirements dimension came in third rank with mean (4.12) and the training and development evaluation dimension came in forth rank with mean (3.93). The mean of independent variable as a whole reached (4.12),

With high rating degree.

The means and standard deviations were completed for study sample individuals attitudes toward items of every dimension of independent variable (impact of training and development function).

Table 4. Means and standard deviations for attitudes of study sample individuals toward all items of training and development strategic importance dimension

\begin{tabular}{|c|c|c|c|c|c|}
\hline \multirow[t]{2}{*}{ Rank } & \multirow[t]{2}{*}{ Number } & Item & \multirow[t]{2}{*}{ Mean } & \multirow{2}{*}{$\begin{array}{l}\text { Standard } \\
\text { deviation }\end{array}$} & \multirow{2}{*}{$\begin{array}{l}\text { Rating } \\
\text { degree }\end{array}$} \\
\hline & & $\begin{array}{l}\text { Training and development opportunities } \\
\text { support employees of the company with . }\end{array}$ & & & \\
\hline 1 & 1 & Succession career & 4.40 & 0.86 & high \\
\hline 2 & 4 & Improving performance & 4.37 & 0.85 & High \\
\hline 3 & 2 & $\begin{array}{l}\text { Acquiring new knowledge, abilities and } \\
\text { skills }\end{array}$ & 4.33 & 0.88 & High \\
\hline 4 & 3 & $\begin{array}{l}\text { Enhancing employees loyalty and } \\
\text { affiliation for their company }\end{array}$ & 4.30 & 0.95 & High \\
\hline 5 & 5 & $\begin{array}{l}\text { Understanding and using modern } \\
\text { technology and techniques quickly }\end{array}$ & 4.27 & 0.83 & high \\
\hline 6 & 6 & Increasing and improving productivity & 4.23 & 0.90 & high \\
\hline 7 & 7 & $\begin{array}{l}\text { Understanding customers needs through } \\
\text { acquisition communications and selling } \\
\text { skills }\end{array}$ & 4.20 & 0.89 & high \\
\hline 8 & 11 & Generating knowledge and sharing & 4.17 & 0.87 & High \\
\hline 9 & 8 & $\begin{array}{l}\text { Promoting company reputation level } \\
\text { through training on business ethics }\end{array}$ & 4.13 & 0.86 & High \\
\hline
\end{tabular}




\begin{tabular}{|c|c|l|c|c|c|}
\hline 10 & 10 & $\begin{array}{l}\text { Maintaining company survival and } \\
\text { prosperity }\end{array}$ & 4.13 & 0.94 & High \\
\hline 11 & 11 & Forming talents inventory for company & 4.13 & 0.86 & high \\
\hline
\end{tabular}

( $\mathrm{n}=30)$ descending order.

\begin{tabular}{|c|c|l|c|c|c|}
\hline Rank & Number & Item & Mean & $\begin{array}{c}\text { Standard } \\
\text { deviation }\end{array}$ & $\begin{array}{c}\text { Rating } \\
\text { degree }\end{array}$ \\
\cline { 2 - 3 } & $\begin{array}{l}\text { Training and development } \\
\text { opportunities support employees of } \\
\text { the company }\end{array}$ & $\begin{array}{l}\text { Understanding learning importance } \\
\text { and investing }\end{array}$ & 4.10 & 0.88 & high \\
\hline 12 & 9 & $\begin{array}{l}\text { Benefit from merger and } \\
\text { acquisition cases by company }\end{array}$ & 4.10 & 0.84 & High \\
\hline 14 & 12 & $\begin{array}{l}\text { Transferring company from } \\
\text { traditional to learning case }\end{array}$ & 4.07 & 0.83 & High \\
\hline & $\begin{array}{l}\text { Training and development strategic } \\
\text { importance as a whole }\end{array}$ & 4.21 & 0.75 & High \\
\hline
\end{tabular}

Table 4 indicates that the means of study individuals attitudes toward the training and development strategic importance reached between(4.07 - 4.40) with high rating degree to all questionnaire items of this dimension. Where the higher item was for the item number (I) (succession career) while the lower item was for the item number (12) ( transferring the company from the traditional to learning case). And the mean of this dimension as a whole reached (4.21) with high rating degree.

Table 5. Means and standard deviations of study sample individuals attitudes toward all items of integrating training and development function with other HRM function dimension $(\mathrm{n}=30)$ descending order

\begin{tabular}{|c|c|c|c|c|c|}
\hline \multirow[t]{2}{*}{ Rank } & \multirow[t]{2}{*}{ Number } & Item & \multirow[t]{2}{*}{ Mean } & \multirow{2}{*}{$\begin{array}{l}\text { Standard } \\
\text { deviation }\end{array}$} & \multirow{2}{*}{$\begin{array}{l}\text { Rating } \\
\text { degree }\end{array}$} \\
\hline & & $\begin{array}{l}\text { Integrating training and development with } \\
\text { other HRM functions contribute with }\end{array}$ & & & \\
\hline 1 & 1 & Forming talents inventory for the company & 4.20 & 0.85 & High \\
\hline 5 & 5 & $\begin{array}{l}\text { Orienting training and development by } \\
\text { depending on planning function to HR } \\
\text { needs }\end{array}$ & 4.17 & 0.79 & High \\
\hline 4 & 3 & $\begin{array}{l}\text { Coming with of training and development } \\
\text { with selection and placement for applicants } \\
\text { specially for top management jobs }\end{array}$ & 4.13 & 0.82 & High \\
\hline 3 & 2 & $\begin{array}{l}\text { Knowing training needs through knowing } \\
\text { job analysis and job design level }\end{array}$ & 4.08 & 0.87 & High \\
\hline \multirow[t]{2}{*}{2} & 4 & $\begin{array}{l}\text { Combining employees performance } \\
\text { evaluation and compensation with training } \\
\text { and development level }\end{array}$ & 4.07 & 0.78 & High \\
\hline & & $\begin{array}{l}\text { Integrating of training and development } \\
\text { dimension with other HRM functions as a } \\
\text { whole }\end{array}$ & 4.13 & 0.77 & \\
\hline
\end{tabular}

Table 5 illustrates that the mean for study sample individuals attitudes toward items of intergrading of training and development dimension with the other HRM functions reached (4.07 - 4.20) with high rating degree to all items of integrating of training and development dimension. Where the higher item was the first item (forming talents inventory for the 
company) while the lower item was item No. 4 (combining employees performance evaluation and compensation with training and development level). The mean of this dimension as a whole reached (4.13) with high rating degree.

Table 6. Means and standard deviations of study sample individuals attitudes toward the whole item of providing successful training requirements dimension. No(30) descending order.

\begin{tabular}{|c|c|c|c|c|c|}
\hline \multirow[t]{2}{*}{ Rank } & \multirow[t]{2}{*}{ Number } & Item & \multirow[t]{2}{*}{ Mean } & \multirow{2}{*}{$\begin{array}{l}\text { Standard } \\
\text { deviation }\end{array}$} & \multirow{2}{*}{$\begin{array}{l}\text { Rating } \\
\text { degree }\end{array}$} \\
\hline & & $\begin{array}{l}\text { Successful training and development } \\
\text { requirements depend on }\end{array}$ & & & \\
\hline 1 & 2 & Top management support & 4.23 & 0.77 & high \\
\hline 2 & 9 & $\begin{array}{l}\text { Information sharing and colleagues } \\
\text { support }\end{array}$ & 4.20 & 0.89 & High \\
\hline 3 & 1 & $\begin{array}{l}\text { Effective training contributes in } \\
\text { improving employees performance } \\
\text { which combine between employees } \\
\text { behavior and outcomes }\end{array}$ & 4.17 & 0.79 & High \\
\hline 3 & 3 & $\begin{array}{l}\text { Employees Readiness and their desire } \\
\text { with learning and training }\end{array}$ & 4.17 & 0.79 & High \\
\hline \multirow[t]{2}{*}{ Rank } & Number & Item & Mean & $\begin{array}{l}\text { Standard } \\
\text { deviation }\end{array}$ & $\begin{array}{l}\text { Rating } \\
\text { degree }\end{array}$ \\
\hline & & $\begin{array}{l}\text { Successful training and development } \\
\text { depend on }\end{array}$ & & & \\
\hline 1 & 2 & Top management support & 4.23 & 0.77 & high \\
\hline 8 & 8 & $\begin{array}{l}\text { Available training means and by } \\
\text { company }\end{array}$ & 4.07 & 0.91 & High \\
\hline 10 & 10 & $\begin{array}{l}\text { Employees placement with good } \\
\text { experience to be instructors }\end{array}$ & 4.03 & 0.89 & High \\
\hline 10 & 7 & $\begin{array}{l}\text { Available enough time for training and } \\
\text { practices by the company. }\end{array}$ & 4.00 & 0.87 & High \\
\hline \multicolumn{3}{|c|}{ successful training requirements dimension as a whole } & 4.12 & 0.72 & high \\
\hline
\end{tabular}

Table 6 illustrates that the means of study sample individuals attitudes toward all items of successful training requirements dimension reached between $(4.00-4.23)$ with high rating degree. Where the higher was item No. 2 ( top management support) and lower item was the item No. 7 (available time enough for training and practices by the company). The mean of the dimension as a whole reached (4.12) with high degree.

Table 7. Means and standard deviations of study sample individuals attitudes toward all items of training and development evaluation dimension

\begin{tabular}{|c|l|l|c|c|c|}
\hline Rank & Number & Item & Mean & $\begin{array}{c}\text { Standard } \\
\text { deviation }\end{array}$ & $\begin{array}{c}\text { Rating } \\
\text { degree }\end{array}$ \\
\hline
\end{tabular}




\begin{tabular}{|c|c|l|c|c|c|}
\hline 1 & 1 & $\begin{array}{l}\text { Issuing booklets which includes } \\
\text { articles with training relation and } \\
\text { interviews with employees who were } \\
\text { succeed in applying new skills }\end{array}$ & H.03 & 0.89 & High \\
\hline 2 & 2 & $\begin{array}{l}\text { Supporting and encourage and } \\
\text { rewarding instructors }\end{array}$ & 4.10 & 0.84 & High \\
\hline 3 & 3 & $\begin{array}{l}\text { Effective training evaluation provide } \\
\text { indicators leads to ideas about } \\
\text { improving training and performance }\end{array}$ & 3.83 & 0.91 & High \\
\hline 3 & 4 & $\begin{array}{l}\text { Training evaluation aims to attract a } \\
\text { lot of applicants }\end{array}$ & 3.83 & 0.91 & High \\
\hline 5 & 5 & $\begin{array}{l}\text { Training evaluation aims to measure } \\
\text { the return on investment }\end{array}$ & 3.90 & 0.92 & High \\
\hline 6 & 6 & $\begin{array}{l}\text { Training evaluation aims to transfer } \\
\text { the know ledge and apply during } \\
\text { working }\end{array}$ & 3.87 & 0.90 & High \\
\hline 7 & 7 & $\begin{array}{l}\text { Training evaluation aims to work } \\
\text { quality and perfect performance }\end{array}$ & 3.97 & 0.93 & High \\
\hline & $\begin{array}{l}\text { Training and development evaluation } \\
\text { dimension as a whole }\end{array}$ & 3.93 & 0.81 & \\
\hline
\end{tabular}

$\mathrm{N}=30 \quad$ descending order

Table 7 illustrates that the means of study sample individuals attitudes toward all items of training and development evaluation dimension reached between (3.97 - 4.03) with high rating degree. Where the higher item was item No. 1 (issuing booklets which includes articles with relation of training and interviews with employees who success in applying the new skills) while the lower item was the item No. 7 (training evaluation aims to work quality and perfect performance). The mean of this dimension as whole reached (3.93) with high rating degree.

Table 8. Means and standard deviations of study sample individuals attitudes toward all items of enhancing competitiveness capacity

\begin{tabular}{|c|c|c|c|c|c|}
\hline \multirow[t]{2}{*}{ rank } & \multirow[t]{2}{*}{ Number } & Item & \multirow[t]{2}{*}{ Mean } & \multirow{2}{*}{$\begin{array}{l}\text { Standard } \\
\text { deviation }\end{array}$} & \multirow{2}{*}{$\begin{array}{l}\text { Rating } \\
\text { degree }\end{array}$} \\
\hline & & $\begin{array}{l}\text { Training and development contributes } \\
\text { with enhancing competitiveness capacity } \\
\text { through }\end{array}$ & & & \\
\hline 1 & 3 & Downsizing production cost & 4.4 & 0.76 & High \\
\hline 2 & 12 & $\begin{array}{l}\text { Enhancing employees ability in using } \\
\text { modern techno logy and techniques }\end{array}$ & 4.10 & 0.84 & High \\
\hline 3 & 14 & $\begin{array}{l}\text { Acquiring knowledge, skills and } \\
\text { competences for employees and enable } \\
\text { the company to invest knowledge capital }\end{array}$ & 4.07 & 0.78 & High \\
\hline 4 & 2 & $\begin{array}{l}\text { Training evaluation aims to create added } \\
\text { value for employees }\end{array}$ & 4.03 & 0.76 & High \\
\hline 4 & 4 & $\begin{array}{l}\text { Producing goods with high quality and } \\
\text { difficult to imitate }\end{array}$ & 4.03 & 0.72 & High \\
\hline
\end{tabular}




\begin{tabular}{|c|c|c|c|c|c|}
\hline \multirow[t]{2}{*}{ rank } & \multirow[t]{2}{*}{ Number } & Item & \multirow[t]{2}{*}{ Mean } & \multirow{2}{*}{$\begin{array}{l}\text { Standard } \\
\text { deviation }\end{array}$} & \multirow{2}{*}{$\begin{array}{l}\text { Rating } \\
\text { degree }\end{array}$} \\
\hline & & $\begin{array}{l}\text { Training and development contributes } \\
\text { with enhancing competitiveness capacity } \\
\text { through }\end{array}$ & & & \\
\hline 6 & 24 & $\begin{array}{l}\text { Training evaluation aims to measure } \\
\text { acquiring knowledge, skills and new } \\
\text { trends }\end{array}$ & 4.00 & 0.91 & High \\
\hline 8 & 5 & $\begin{array}{l}\text { Increasing the production and improving } \\
\text { the productivity }\end{array}$ & 3.97 & 0.76 & High \\
\hline 8 & 11 & Using the economy scale method & 3.97 & 0.81 & High \\
\hline 12 & 15 & $\begin{array}{l}\text { Empowering the company to gain bigger } \\
\text { market share }\end{array}$ & 3.93 & 0.74 & High \\
\hline 12 & 29 & $\begin{array}{l}\text { Improving employees performance and } \\
\text { company as a whole }\end{array}$ & 3.93 & 0.83 & High \\
\hline 14 & 9 & $\begin{array}{l}\text { Increasing employees loyalty to the } \\
\text { company }\end{array}$ & 3.90 & 0.80 & High \\
\hline 14 & 10 & $\begin{array}{l}\text { Increasing customers and consumers } \\
\text { loyalty to the company's trade mark }\end{array}$ & 3.90 & 0.80 & High \\
\hline 14 & 18 & $\begin{array}{l}\text { Developing and diverse company's } \\
\text { products }\end{array}$ & 3.90 & 0.84 & High \\
\hline 14 & 19 & Achieving profits to the company & 3.90 & 0.84 & High \\
\hline 14 & 20 & $\begin{array}{l}\text { Using electric commercial method to } \\
\text { fulfill duties quickly }\end{array}$ & 3.90 & 0.84 & High \\
\hline 21 & 17 & $\begin{array}{l}\text { Protecting company's resources from } \\
\text { sabotage and wasting }\end{array}$ & 3.87 & 0.73 & High \\
\hline 21 & 22 & Increasing employees motivation to work & 3.87 & 0.73 & High \\
\hline 21 & 25 & $\begin{array}{l}\text { Encouraging initiative entrepreneurship, } \\
\text { risk and innovation }\end{array}$ & 3.83 & 0.79 & High \\
\hline \multirow[t]{2}{*}{ rank } & \multirow[t]{2}{*}{ Number } & Item & \multirow[t]{2}{*}{ Mean } & \multirow{2}{*}{$\begin{array}{l}\text { Standard } \\
\text { deviation }\end{array}$} & \multirow{2}{*}{$\begin{array}{l}\text { Rating } \\
\text { degree }\end{array}$} \\
\hline & & $\begin{array}{l}\text { Training and development contributes } \\
\text { with enhancing competitiveness capacity } \\
\text { through }\end{array}$ & & & \\
\hline 27 & 28 & Decreasing manufacturing cycle time & 3.80 & 0.76 & High \\
\hline \multirow[t]{2}{*}{27} & 16 & $\begin{array}{l}\text { Achieving customers satisfaction } \\
\text { through providing them with cheaper and } \\
\text { high quality goods }\end{array}$ & 3.80 & 0.85 & High \\
\hline & & Competitiveness capacity as a whole & 3.92 & 0.66 & High \\
\hline
\end{tabular}

$\mathrm{N}=30$ descending order

Table 8 illustrates that the means of study sample individuals attitudes toward the competitiveness capacity items, where reached between $(3.80-4.11)$ with high rating degree 
to all items, where the higher item was No. 3 Training and development contributes with (downsizing), while the lower item was to item No. 28 (decreasing manufacturing cycle time). The mean of competitiveness capacity as dependent variable as whole reached (3.92) with high rating degree.

To verity the validity of the study hypotheses, multiple regression equation was caring out to examine the impact of training and development dimensions on enhancing competitiveness capacity

Table 9. The results of multiple regression application to study the impact of training and development dimensions on enhancing competitiveness capacity for industrial companies

\begin{tabular}{|c|c|c|c|c|c|c|c|c|}
\hline No & Dimension & $\beta$ & $\mathrm{T}$ & $\begin{array}{l}\text { Statistical } \\
\text { significant }\end{array}$ & $\mathrm{R}$ & $\mathrm{R} 2$ & $\mathrm{~F}$ & sig \\
\hline 1 & $\begin{array}{l}\text { Training development } \\
\text { strategic importance }\end{array}$ & 0.01 & 0.03 & 0.98 & & & & \\
\hline 2 & $\begin{array}{l}\text { Integrating Training } \\
\text { and development } \\
\text { function with the other } \\
\text { HRM functions }\end{array}$ & 0.10 & 0.37 & 0.71 & 0.84 & 0.70 & 14.65 & 0.00 \\
\hline 3 & $\begin{array}{l}\text { Successful training } \\
\text { requirements }\end{array}$ & 0.82 & 2.82 & 0.01 & & & & \\
\hline 4 & $\begin{array}{l}\text { Training and } \\
\text { development } \\
\text { evaluation }\end{array}$ & 0.13 & 0.67 & 0.51 & & & & \\
\hline
\end{tabular}

Table 9 illustrates that the results as follows:

First sub hypothesis: there is no impact with statistical significant at significant level $(0.05 \geq$ $\alpha$ ) of training and development strategic importance on enhancing competitiveness capacity. Where (T.B) values reached $(0.03,0.01)$. it is positive values and it is not statistical significant. So we reject the H1: hypothesis and accept Ho hypothesis, second sub hypothesis: there is no impact with statistical significant at significant level $(0.05 \geq \alpha)$ of integrating training and development function with other HRM functions on enhancing competitiveness capacity, where the $(T, \beta)$ values reached $(-0.37,-0.10)$ it is negative values and it is not statistical significant. So we reject the H1: hypothesis and accept Ho hypothesis.

Third sub hypothesis: There is no impact with statistical significant at significant level (0.05 $\geq \alpha$ ) of successful training requirements on enhancing competitiveness capacity, where the $(T, \beta)$ values reached $(2.82,0.82)$ it is positive values and statistical significant, so we accept H1, hypothesis and reject Ho hypothesis.

Forth sub hypothesis: there is no impact with statistical significant at significant level $(0.05 \geq$ $\alpha)$ of training and development evaluation on enhancing competitiveness capacity, where the $(T, \beta)$ values reached $(0.67,0.13)$ it is positive values and not statistical significant so we 
reject H1: hypothesis and accept Ho hypothesis.

The main hypothesis result: There is no impact with statistical significant at significant level $(0,05 \geq \alpha)$ of training and development dimensions on enhancing competitiveness capacity, as (Training and development strategic importance, Integrating training and development function with other HRM functions, successful training requirements, training and development evaluation). Where the correlation coefficient factor $(\mathrm{R})$ reached (0.84), it is statistical significant value. And indicates that there is high correlation degree with statistical significant among independent variables and dependent variable, where the ( $\mathrm{R}$ - square) value reached $(0.70)$ it is statistical significant value. Which explain the impact of training and development dimensions on enhancing competitiveness capacity where the (f) test value reached (14.45) with statistical significant (0.00), it is statistical significant at significant level $(0.05 \geq \alpha)$ therefore it indicates that there is statistical significant relation between independent variable and dependent variable.

So we accept H1:the main hypothesis and reject Ho: hypothesis.

\section{Conclusion}

All Pearson correlation coefficient values are statistically significant at significant level (0.05 $\geq \alpha$ ) where the reliability of study tool as a whole reached $(0.85)$ and correlation coefficient reached (0.77) therefore it is acceptable for the application purposes.

The importance degree of independent variable dimensions according to the means of study sample individuals attitudes toward the independent variable dimensions as following sequence (training and development strategic importance, integrating of training and development function with other HRM functions, successful training requirements, and training and development evaluation ), all of these dimensions came in high degree of impact on enhancing competitiveness capacity.

All means of study sample individuals attitudes toward all items of enhancing competitiveness capacity (dependent variable) came in high degree, specially the item No. 3 (training and development contributes with increasing and improvement productivity) .

The multiple regression results indicates that there is no impact of all dimensions of training and development function on enhancing competitiveness capacity exceptional successful training requirements dimension.

The results of main hypothesis indicates that there is impact with statistical significant at significant level $(0.05 \geq \alpha)$ for the training and development function on enhancing competitiveness capacity of Jordanian industrial companies, where the correlation coefficient value ( $\mathrm{R}$ ) reached $(0.84)$, so it indicates that there is statistically significant correlation between independent variable and dependent variable ,and the value of ( $\mathrm{R}$-square ) reached $(0.70)$, so it is statistically significant value and explain the strength impact of the training and development function on enhancing competitiveness capacity, where the value of (Ftest)reached (14.45) with statistically significant (0.00) which indicates that there is 
statistically significant at significant level $(0.05 \geq \alpha)$ therefore we accept the alternative hypothesis and reject null hypothesis.

\section{Recommendations}

Researchers have to apply this study in future on the other Sectors as hotels, banks insurance, communications, NGOs, ,CSOs , etc, organizations.

Industrial companies have to establish special training unit in medium and large companies.

Industrial companies have to deduct a reasonable ratio from its annual profits for training and development.

\section{References}

Barney, J. (1986). Organizational culture: can it be a source of sustained competitive advantage? Academy of management Review, 11(3), 656 - 665.

Barney, J. (1991). Firm resources and sustained competitive advantage. Journal of management, 17(1), $99-120$.

Becker, G. S. (1993). Human capital: A theoretical analysis with special reference to education (3 thed.) Chicago, 11: university of Chicago press.

Billet, S., \& Cooper, M. (1997). Returns to enterprises from investment in VET. A dlaide, Australia: National Center for vocational and Educational Research.

Coulter, M. (2005). Strategic management in Action. New York: Printic Hall. Page, 191 196.

Dessaler, G. (2011). human resource management, 12th edition, Pearson Education limited, Edinburgh Gate, hallow Essex Cm 20 SJE England 323.

Hendry, C., \& Pettigrew, A. (1989). The forces that trigger training, personnel management, 20(12), $28-32$.

Heyes, J., \& Stuart, M. (1996). Does training matter? Employee experiences and attitudes. Human resource management Journal, 6 (3), 7 - 21.

Jackson, et al., managing HR, PP 270-273: Huff, C. (2005). Accent on training, workforce management (March, 2005): 54; Fraquenheim, E. (2005). Culture of understanding workforce management (Vor. 2005) 26 - 30) Gupta S.C. (2009). Advanced HR strategic management strategic perspective, New Delhi ane Books prt, Ltd, PP, 271 - 72.

Jackson,S., schculer, R., \& Werner, S. (2009). Management Human resources $10^{\text {th }}$ ed Mason, $\mathrm{OH}$ : Sauth - western Cergage learning, P. 275.

Jelena, V. D. (2009). Development of human resources as strategic factors of the companies advantage Ud 005. 96 , Facte university. 
Johenson, G., Scholes, K., \& Whittington, R. (2008). Exploring corporate strategy / the Edition, pearson Education limited.

Noe, R., Hollenbeck, J., Gerhart, B., \& Wright, P. (2011). Fundamentals, of human resources management, New York megarow - Hill, p. 223.

Olumuyiwa, S. O. (2012). Training and development, a vital tool for organizational effectiveness. A case study of sterling Bank Nigeria Plc.IOSR Journal of Business and management (IOSR - 3BM). ISSN:2278 - 487x. volume 6, Issue 2 (NOV. Dec. 2012 QP 48 57).

Peteraf, M. A. (1993). The cornerstones of competitive advantage: Aresource - based view. Strategic management Journal, 14(3), 179 - 192.

Porter, \& Stern (2002). National Innovative capacity. In M. E. Porter, J. D. Sachs, P. K. Cornelius, J. W. M., \& Arthur, K. S. (eds). The global competitiveness porter (1980) Report 2001 - 2002, NewYork: Oxford university press, 02 - 118.

Porter, M. E. (1980). Competitive strategy: Techniques for analyzing industries and competitors. NewYork, : free press.

Porter, M. E. (1998). Clusters and the new economics of competition, Harvard Business Review, 76(6), 77 - 90.

Porter, M. E.(2000). Location, competition, and economic development: Local clusters in a global economy. Economic development Quarterly, 14(V), 15 - 34.

Rogers, M. (1998). The definition and measurement of innovation. Melbourne, Australia: university of Melbourne, Melbourne Institute.

Scott, B. (2007). What impact does training have on employee commitment and employee turnover? University of Rhode Island Brun, (2007) Schmidt laber research center seminar research.

Sum, V. (2010a). The role of training and firms Competitiveness in the knowledge - based economy, proceedings of the MTMI-TRW 2010 International conference on Emerging paradigms and practices in business management / Technology management Kloops. British Columbia, Canada.

Vichet, S. (2010). Integrating training in business strategies means greater impact of training on firm,s competitiveness, University of Maryland and Eastern Shore, research in business and economics Journal.

Wheelen, T. L., \& Hunge, D. J. (2010). Startegic management and business policy, 12th edition, Pearson Education, Inc., publishing as prentice. Hall, one Lake street, upper saddle river, New Jersey. 


\section{Macrothink}

\section{Copyright Disclaimer}

Copyright for this article is retained by the author(s).

This is an open-access article distributed under the terms and conditions of the Creative Commons Attribution license (http://creativecommons.org/licenses/by/3.0/). 